\title{
Agronomic performance evaluation of cowpea seeds holed by the cowpea seed bruchids, Callosobruchus maculatus $(F$.$) in the screen house$
}

\author{
Adebayo, R. A. ${ }^{*}$, Osobase, F. I. ${ }^{1}$ and Adesina, J. M. ${ }^{2}$ \\ ${ }^{1}$ Department of Crop, Soil and Pest Management, School of Agriculture and Agricultural Technology, Federal University \\ of Technology, P. M. B. 704, Akure, Nigeria. \\ ²Department of Crop, Soil and Pest Management, Rufus Giwa Polytechnic, Owo, Ondo State, Nigeria. \\ *Corresponding author. Email: raphael.adebayo@yahoo.com, raadebayo@futa.edu.ng. Tel: +234 7038661128.
}

Copyright ( 2018 Adebayo et al. This article remains permanently open access under the terms of the Creative Commons Attribution License 4.0, which permits unrestricted use, distribution, and reproduction in any medium, provided the original work is properly cited.

Received 16th February, 2018; Accepted 12th March, 2018

\begin{abstract}
Agronomic performance of Oloyin cowpea seeds holed by Callosobruchus maculatus was evaluated at the Department of Crop, Soil and Pest Management, Federal University of Technology, Akure, Nigeria. Seeds with emergent holes (1, 2, 3 and 4) and seeds without holes were separately sown in five litre plastic buckets filled with sandy loam soil in the screen house and replicated three times. Data on percentage emergence, number of leaves, number of branches, plant height, plant girth, number of pods, number of seeds per pod, pod length and weight of seeds were collected fortnightly for eight weeks and subjected to analysis of variance. Percentage seedling emergence (20\%) obtained from seeds with 4 emergent holes was significantly $(p<0.05)$ lower than $86.70 \%$ obtained in seeds with one emergent hole. Seeds with 4 emergent holes recorded significantly lower growth parameters. The number of pods were not significantly $(p>0.05)$ affected by the number of emergent holes at 6 and 8 weeks after sowing. Total number and weight of seeds per plot were not significantly different $(p>0.05)$. The study showed that although the agronomic performance of seeds with $\geq 3$ emergent holes was affected during early stage of growth, there were compensatory effects after establishment. Therefore, based on the findings of this study, it is recommended that seeds with $\leq 4$ bruchids emergent holes that are rejected for consumption could be planted instead of total discard.
\end{abstract}

Keywords: Agronomic performance, cowpea seeds, Callosobruchus maculatus, emergent hole.

\section{INTRODUCTION}

Legumes occupy a prominent place in the nutrition of Nigerians because their edible seeds provide cheap alternative source of dietary protein (Ofuya, 2001; Ofuya and Adedire, 2004; Adedire et al., 2011; lleke and Olotuah, 2012). Their seeds are veritable sources of minerals (such as calcium, iron), vitamins, fat, thiamine and riboflavin (Nelson, 1991) and serve as sources of protein to people who cannot afford animal protein derivable from fish, meat, milk and eggs (Egho, 2010; Augustine, 2011). The major food legumes cultivated in Nigeria are Cowpeas (Vigna unguiculata (L.) Walp), Pigeon pea (Cajanus cajan (L.) Mills), Mung bean (Vigna radiata (L.) Wukezek), African yam bean (Sphenostylis stenocarpa Hochst) and Green gram (Vigna mung (L.) Hepper). Cowpea, one of the several species of the widely cultivated genus Vigna, is an annual legume crop and one of the most important food legume crops in the semi-arid tropics (Singh et al., 2003). A drought tolerant and warm weather crop, cowpeas are well adapted to the drier regions of the tropics, where other food legumes do not perform well. It has the ability to fix atmospheric nitrogen through its root nodules and it grows well in poor soils with more than $85 \%$ sand and less than $0.2 \%$ organic matter and low levels of phosphorus (Singh et al., 2003). Apart from being an important source of food for humans, this crop is also used as feed for livestock.

Callosobruchus maculatus is major pest of cowpea that affects yield, integrity of tissue component and developmental stage of the plant. A female adult can lay 
over a hundred eggs, and most of them will hatch. Eggs are laid on the surface of a bean, and when the larva emerges about 4 to 8 days later it burrows into the bean (Raina, 1970). During development, the larva feeds on the interior of the bean, eating the tissue under the surface. It leaves a very thin layer through which it exits when matured thereby producing emergent holes. Effects of seed feeding beetles included low yield in cowpea due to damages such as weight loss and seeds riddled with exit holes (Olatunde et al., 1991; Egho, 2011; Diouf, 2011; Adebayo et al., 2013). This has made production of cowpea difficult and unprofitable. Adebayo and Idoko (2012) opined that cowpea seeds damaged by $C$. maculatus are quantitatively and qualitatively reduced as grain and seeds for humans but could be included in compounding animal feeds. There were reductions in the radicle and plumule emergence, growth and yield parameters of infested cowpea seeds when the position of the emergent holes was considered (Anonymous, 2012). Therefore, the objective of the study is to evaluate the effects of number of emergent holes on the performance of holed cowpea seeds.

\section{MATERIALS AND METHODS}

\section{Study area}

The study was carried out at the Pest Management laboratory and the screen house of the Department of Crop, Soil and Pest Management, Federal University of Technology, Akure, Ondo State, Nigeria.

\section{Experimental procedures}

Infested cowpea seeds holed by C. maculatus were sorted into seeds lots bearing no hole, 1, 2, 3 and 4 emergent hole(s). The experiment was conducted as a Completely Randomized Design with three replications. Seeds were sown into $5 \mathrm{~L}$ plastic buckets filled with sandy loam soil. Five seeds were sown circularly in the buckets and later thinned to three seedlings after emergence. Each bucket was watered twice a week to field capacity. Five days after emergence, data were collected on number of seedlings with which percentage emergence was calculated. Number of leaves, plant height, plant girth and number of branches were measured forthnightly $(2,4,6$ and 8 weeks after sowing). At harvest, data were collected on the number of pods, number of seeds per pod, length of pod and weight of seeds per pod.

\section{Data analysis}

Prior to the analysis, data taking by counting were square root transformed while the data calculated to percentage were arcsine transformed. Transformed data were subjected to analysis of variance (ANOVA) using SPSS version 17. Means were separated with Tukey's HSD test at $5 \%$ level of significance and results presented in Tables.

\section{RESULTS}

Percentage emergence was significantly different among seeds with different number of emergent holes. Significantly highest percentage $(86.70 \%)$ was recorded with seeds bearing a hole while lowest percentage $(20.00 \%)$ was recorded with seeds bearing four emergent holes. However, there was no significant difference ( $p>0.05$ ) among seeds having two, three or zero (control) emergent holes (Table 1).

Results on the number of leaves and plant height of seedlings produced with varying numbers of emergent holes are presented in Table 2. At two weeks after sowing, significantly highest number of leaves (1.99) was recorded on seeds without hole while significant lowest number of leaves (1.14) obtained on seeds bearing four emergent holes. However, there was no significant difference ( $p>0.05$ ) among seeds having 2 and 3 emergent holes and the control. At the 8th weeks after planting lowest number of leaves (1.48) was obtained on seeds with four holes and was significantly different $(p<0.05)$ from others. The plant height increased steadily with the number of weeks after planting. The plant height at 8th weeks after planting was significantly highest (107.00) in seeds with one hole and was significantly lowest (11.50) in the seeds containing four emergent holes.

Plant girth and number of branches from the seeds having varying number of emergent holes were different statistically $(p<0.05)$. Plant girth increased with weeks after planting. Highest plant girth was recorded in the control, seed with one and two holes but was least in the seeds bearing four holes. Number of branches were highest in the control and seeds with one hole while it was least in the seeds with four holes but were not significantly different $(p<0.05)$ from each other (Table 3$)$.

There were no significant differences $(p>0.05)$ on mean number of pods among the seeds bearing different number of emergent holes at 6 and 8 weeks after planting (Table 4). Significant highest number of pods (1.52) was recorded on seeds bearing an emergent hole and was significantly higher $(p<0.05)$ than the mean value of pods (1.14) obtained on seeds bearing three and four emergent holes (1.17).

There was no significant difference $(p>0.05)$ among the mean number of pods and pod length at 10th week after planting. Significant highest number of pods (1.99) was recorded on seeds with two emergent holes while lowest (1.33) was obtained on seeds with three (3) and four (4) emergent holes (Table 5). Significantly higher pod length (13.90) was recorded on seeds with 3 emergent holes while lowest pod length (12.60) was recorded on seeds with 4 emergent holes. Total number of seeds and weight of seeds per pods were significantly different $(p<0.05)$. 
Table 1. Percentage emergence of cowpea seeds bearing different number of emergent holes.

\begin{tabular}{lc}
\hline Treatments & Percentage emergence (\%) \\
\hline Control & $60.00^{\mathrm{ab}}$ \\
One hole & $86.70 \mathrm{a}$ \\
Two holes & $60.00^{\mathrm{ab}}$ \\
Three holes & $46.70^{\mathrm{ab}}$ \\
Four holes & $20.00^{\mathrm{b}}$ \\
\hline
\end{tabular}

Means bearing the same alphabet(s) along the column are not significantly different using Tukey's test at $5 \%$ level of significance.

Table 2. The effects of number of emergent holes on the number of leaves and plant height of cowpea seeds at 2, 4, 6 and 8 weeks after planting.

\begin{tabular}{lcccccccc}
\hline \multirow{2}{*}{ Treatments } & \multicolumn{3}{c}{ No of leaves per Weeks } & \multicolumn{3}{c}{ Plant height (cm) per weeks } \\
\cline { 2 - 8 } & $\mathbf{2}$ & $\mathbf{4}$ & $\mathbf{6}$ & $\mathbf{8}$ & $\mathbf{2}$ & $\mathbf{4}$ & $\mathbf{6}$ & $\mathbf{8}$ \\
\hline Control & $2.89^{\mathrm{ab}}$ & $1.99^{\mathrm{a}}$ & $3.25^{\mathrm{a}}$ & $3.36^{\mathrm{a}}$ & $10.20^{\mathrm{a}}$ & $62.90^{\mathrm{a}}$ & $92.87^{\mathrm{a}}$ & $94.60^{\mathrm{a}}$ \\
One hole & $1.87^{\mathrm{a}}$ & $3.50^{\mathrm{a}}$ & $3.60^{\mathrm{a}}$ & $3.41^{\mathrm{a}}$ & $14.70^{\mathrm{a}}$ & $48.87^{\mathrm{a}}$ & $59.93^{\mathrm{a}}$ & $107.00^{\mathrm{a}}$ \\
Two holes & $1.80^{\mathrm{a}}$ & $3.21^{\mathrm{a}}$ & $3.38^{\mathrm{a}}$ & $3.38^{\mathrm{a}}$ & $27.77^{\mathrm{a}}$ & $56.83^{\mathrm{a}}$ & $62.50^{\mathrm{a}}$ & $68.77^{\mathrm{ab}}$ \\
Three holes & $1.69^{\mathrm{ab}}$ & $3.76^{\mathrm{ab}}$ & $2.52^{\mathrm{ab}}$ & $2.52^{\mathrm{ab}}$ & $22.70^{\mathrm{a}}$ & $36.53^{\mathrm{a}}$ & $41.60^{\mathrm{a}}$ & $43.47^{\mathrm{ab}}$ \\
Four holes & $1.14^{\mathrm{b}}$ & $1.46^{\mathrm{b}}$ & $1.48^{\mathrm{b}}$ & $1.48^{\mathrm{b}}$ & $1.67^{\mathrm{b}}$ & $1.67^{\mathrm{b}}$ & $10.43^{\mathrm{b}}$ & $11.50^{\mathrm{b}}$ \\
\hline
\end{tabular}

Means bearing the same alphabet(s) along the column are not significantly different using Tukey's test at $5 \%$ level of significance.

Table 3. The effects of number of emergent holes on the plant girth and number of branches of cowpea at 2, 4, 6 and 8 weeks after planting.

\begin{tabular}{lcccccccc}
\hline \multirow{2}{*}{ Treatments } & \multicolumn{3}{c}{ Plant girth in cm per weeks } & \multicolumn{4}{c}{ Number of branches per weeks } \\
\cline { 2 - 9 } & $\mathbf{2}$ & $\mathbf{4}$ & $\mathbf{6}$ & $\mathbf{8}$ & $\mathbf{2}$ & $\mathbf{4}$ & $\mathbf{6}$ & $\mathbf{8}$ \\
\hline Control & $3.33^{\mathrm{b}}$ & $4.13^{\mathrm{a}}$ & $4.23^{\mathrm{a}}$ & $4.47^{\mathrm{a}}$ & $1.14^{\mathrm{a}}$ & $1.58^{\mathrm{ab}}$ & $1.61^{\mathrm{a}}$ & $1.61^{\mathrm{a}}$ \\
One hole & $3.63^{\mathrm{ab}}$ & $4.37^{\mathrm{a}}$ & $4.73^{\mathrm{a}}$ & $5.63^{\mathrm{a}}$ & $1.65^{\mathrm{a}}$ & $1.89^{\mathrm{a}}$ & $1.65^{\mathrm{a}}$ & $1.65^{\mathrm{a}}$ \\
Two holes & $3.13^{\mathrm{b}}$ & $3.97^{\mathrm{a}}$ & $4.43^{\mathrm{a}}$ & $5.07^{\mathrm{a}}$ & $1.52^{\mathrm{a}}$ & $1.59^{\mathrm{ab}}$ & $1.52^{\mathrm{a}}$ & $1.52^{\mathrm{a}}$ \\
Three holes & $5.07^{\mathrm{a}}$ & $2.80^{\mathrm{a}}$ & $3.53^{\mathrm{a}}$ & $4.03^{\mathrm{a}}$ & $1.43^{\mathrm{a}}$ & $1.31^{\mathrm{ab}}$ & $1.42^{\mathrm{a}}$ & $1.42^{\mathrm{a}}$ \\
Four holes & $0.40^{\mathrm{c}}$ & $0.53^{\mathrm{b}}$ & $0.67^{\mathrm{b}}$ & $0.80^{\mathrm{b}}$ & $1.34^{\mathrm{a}}$ & $1.14^{\mathrm{b}}$ & $1.17^{\mathrm{a}}$ & $1.17^{\mathrm{a}}$ \\
\hline
\end{tabular}

Means bearing the same alphabet(s) along the column are not significantly different using Tukey's test at $5 \%$ level of significance.

Table 4. Effects of the number of emergent holes on the mean number of pods at 6 and 8 weeks after planting.

\begin{tabular}{lcc}
\hline \multirow{2}{*}{ Treatments } & \multicolumn{2}{c}{ No of pods } \\
\cline { 2 - 3 } & Week 6 & Week 8 \\
\hline Control & $1.15^{\mathrm{a}}$ & $1.47^{\mathrm{a}}$ \\
One hole & $1.29^{\mathrm{a}}$ & $1.52^{\mathrm{a}}$ \\
Two holes & $1.18^{\mathrm{a}}$ & $1.44^{\mathrm{a}}$ \\
Three holes & $1.34^{\mathrm{a}}$ & $1.14^{\mathrm{a}}$ \\
Four holes & $1.17^{\mathrm{a}}$ & $1.17^{\mathrm{a}}$ \\
\hline
\end{tabular}

Means bearing the same alphabet(s) along the column are not significantly different using Tukey's test at $5 \%$ level of significance. 
Table 5. Effects of number of emergent holes on mean number of pods, pod length, number of seeds and mean weight of seeds at ten (10) weeks after planting.

\begin{tabular}{lcccc}
\hline Treatments & Mean no of pods & Pod length $(\mathbf{c m})$ & Total no of seeds & Mean weight of seeds $(\mathbf{g})$ \\
\hline Control & $1.91^{\mathrm{a}}$ & $12.70^{\mathrm{a}}$ & $2.64^{\mathrm{a}}$ & $3.67^{\mathrm{a}}$ \\
One hole & $1.88^{\mathrm{a}}$ & $10.87^{\mathrm{a}}$ & $2.89^{\mathrm{a}}$ & $4.00^{\mathrm{a}}$ \\
Two holes & $1.99^{\mathrm{a}}$ & $13.63^{\mathrm{a}}$ & $3.05^{\mathrm{a}}$ & $4.00^{\mathrm{a}}$ \\
Three holes & $1.33^{\mathrm{a}}$ & $13.90^{\mathrm{a}}$ & $1.72^{\mathrm{b}}$ & $2.00^{\mathrm{ab}}$ \\
Four holes & $1.33^{\mathrm{a}}$ & $12.60^{\mathrm{a}}$ & $1.72^{\mathrm{b}}$ & $1.67^{\mathrm{b}}$ \\
\hline
\end{tabular}

Means bearing the same alphabet(s) along the column are not significantly different using Tukey's test at $5 \%$ level of significance.

Seeds with 2 emergent holes have significant highest number (3.05) of seeds per pods while the lowest number of seeds per pods (1.72) was obtained in seeds with 3 and 4 emergent holes.

The weight of the seeds was significantly higher (4.00) in the seeds with 1 and 2 emergent holes and was lowest (1.67) in seeds with 4 emergent holes (Table 5).

\section{DISCUSSION}

This study shows that heavily infested cowpea seeds with many emergent holes have low percentage germinability and this agrees with the earlier reports by Ofuya and Agele (1990) and Ofuya (2003) who concluded that damage to the seeds of cowpea by the bruchids beetles negatively affect the germinability of the seeds and caused reduction in weight. Observation from the study also shows that there were reductions in some of the parameters such as number of leaves and number of branches during growth and development due to the emergent holes created by $C$. maculatus on the seeds. This confirms the report that infestation by the cowpea seed beetle can result in a significant reduction in germination and yield of cowpea (Ofuya, 2003; Adebayo et al., 2013). The study also showed that cowpea seeds infested with C. maculatus were affected at stages of growth. This might be due to reduction in size of the endosperm occasioned by the feeding activity of larvae. Effects of seed feeding beetles were reported to cause low yield in cowpea as a result of the damage caused such as weight loss and seeds riddled with exit holes (Olatunde et al., 1991; Egho, 2010; Diouf, 2011; Adebayo et al., 2013). This has made production of cowpea difficult and unprofitable. Adebayo and Idoko (2012) in a study opined that seeds damaged through infestation by $C$. maculatus though were both quantitatively and qualitatively affected as grain and seeds, suggested that the damaged seeds should be utilized as inclusion in animal feeds. There has been report of reduction in the radicle and plumule emergence, growth and yield parameters of infested cowpea seeds when the position of the emergent holes was considered (Anonymous, 2012). The vigor of the holed cowpea seed was affected at earlier stage of growth and subsequently affected the number of leaves, girth and number of branches; this could also be as a result of damage and reduction to the endosperm of the holed seeds. At the later stage of development of the holed seeds, there seems to be a compensatory effect which improved the performance of the heavily holed ( 3 and 4 holes) seeds. In this study, mean weight of seeds and number of seeds in pod were lower in plants produced from 3 and 4 emergent holed seeds. This is probably why floatation method is used to determine seeds that are suitable for sowing since light weight seeds might result in poor germination, reduced vigor and yield.

\section{Conclusion}

Based on the results obtained, it was concluded that emergent holes in infested cowpea seeds have effects on the growth performance of cowpea at the early growing stage of cowpea. This consequently caused significant effect on the yield parameters when the seeds were severally holed. Seeds with two emergent holes compared favorably with those without holes while seeds bearing four emergent holes were negatively affected in their measured growth and yield parameters. It was therefore, recommended that seeds of cowpea that are unfit for consumption ( 3 or 4 emergent holed cowpea seeds) should be utilized as planting material instead of total discard.

\section{CONFLICT OF INTEREST}

The authors declare that they have no conflict of interest.

\section{REFERENCES}

Adebayo, R. A., \& Idoko, J. E. (2012) Influences of Callosobruchus maculatus (F) [Coleoptera:Bruchidae] infestation on food quality of three local varieties of cowpea in Akure Ondo State. International Journal of Agriculture and Food Science, 3(9), 277-286.

Adebayo, R. A, Idoko, J. E., \&Adetuyi, R. O. (2013); Response of four local varieties of cowpea to water extract of Chromolena odoratus (Kings and Robinson) and Verononia amygdalina (L.). International journal of Agriculture and food science, (1 and 2), 447- 456. 
Adedire, C. O., Obembe, O. O., Akinkurolele, R. O., \& Oduleye, O. (2011). Response of Callosobruchus maculatus (Coleoptera: Chysomelidae: Bruchinae) to extracts of cashew kernels. Journal of Plant Diseases and Protection, 118(2): 7579.

Anonymous (2012). Effect of positions of bruchids emergent holes on the performance of planting cowpea seeds. Personal communication.

Augustine, S. N. (2011). Arthropod assemblage dynamics on cowpea (Vigna unguiculata L. Walp) in a subtropical agroecosystem, South Africa. African Journal of Agricultural Research, 6(4), 1009-1015.

Diouf, D. (2011). Recent advances in cowpea [Vigna unguiculata (L.) Walp.] "omics" research for genetic improvement. African Journal of Biotechnology, 10(15), 2803-2810.

Egho, E. O. (2010). Management of major field insect pests and yield of cowpea (Vigna unguiculata $(L)$ Walp) under calendar and monitored application of synthetic chemicals in Asaba, Southern Nigeria. African Journal of General Agriculture, 6(3), 177-186.

Egho, E.O. (2011). The potentials of mineral oils for controlling the major insect pests of cowpea (Vigna unguiculata (L.) Walp in Asaba, Nigeria. Agriculture and Biology Journal of North America, 2(3), 454-461

lleke, K. D., \& Olotuah, O. F. (2012). Bioactivity of Anacardium occidentale (L) and Allium sativum (L) powders and oils extracts against cowpea bruchid, Callosobruchus maculatus (Fab.) [Coleoptera: Chrysomelidae]. International Journal of Biology, 4(1), 96.

Nelson, S. N. (1991). Digestibility of Legume Protein. Food Technology, 45, 112-114.
Ofuya, T. I. (2003). Beans, insects and man. Inaugural lecture series 35. The Federal University of Technology, Akure, Nigeria. $45 p$.

Ofuya, T. I. (2001). Biology, Ecology and control of insect pests of stored Food legumes. Dave Collins publications, Nigeria. Pp 59-94.

Ofuya, T. I., \& Agele S. O. (1990). Ability of ovipositing Callosobruchus-maculatus (Fabricius) (Coleoptera, Bruchidae) females to discriminate between seeds with differing numbers of emergence holes. Journal of Stored Products Research, 26,117-120.

Ofuya, T. I., \& Adedire C. O. (2004). Sustainable protection of stored crops against insect depredation in tropics. 2(152-165). College Press and Publisher Ltd, Ibadan Nigeria.

Olatunde, G. O., Odebiyi, J. A., Chiang, H. S., \& Jackai, L. E. N. (1991). Identification of sources of resistance in cowpea, Vigna unguiculata L. Walp. to Clavigralla tomentosicollis Stal. (Hemiptera: Coreidae). International Journal of Tropical Insect Science, 12(4), 455-461.

Raina, A. K. (1970). Callosobruchus spp. infesting stored pulses (grain legumes) in India and comparative study of their biology. Indian Journal of Entomology, 32(4), 303-10.

Singh, B., Ajeigbe, H. A., Tarawali, S. A., Fernandez-Rivera, S., and Abubakar, M. (2003). Improving the production and utilization of cowpea as food and fodder. Field Crops Research,84, 169-150. 